\title{
THE WOLFF-PARKINSON-WHITE SYNDROME IN INFANCY AND CHILDHOOD
}

\author{
BY \\ JERZY ŚWIDERSKI, MARTIN H. LEES, AND ALEXANDER S. NADAS
}

From the Department of Pediatrics, Harvard Medical School, and the Sharon Cardiovascular Unit of the Children's Hospital Medical Center, Boston, Mass., U.S.A.

Received March 27, 1962

Surveys of the Wolff-Parkinson-White syndrome in children have appeared since 1944 (Lind, 1944; Engle, 1952; Fiorio, 1953; Seganti and Varcasia, 1954; Bulgarelli, 1955; Tamm, 1956; Schiebler, Adams and Anderson, 1959a; Sroczynska and Korczowski, 1959). The most extensive is that of Schiebler et al. (1959a), presenting 28 cases who were first seen under the age of 16 years. Our paper, by presenting a group of 48 children, is intended to delineate further its incidence, natural history, and the problems associated with the lesion. No attempt will be made to elaborate on the anatomy and physiology of the pre-excitation syndrome.

\section{Material AND Methods}

The records of 48 patients in whom a definite diagnosis of the Wolff-Parkinson-White (WPW) syndrome could be made were found in the electrocardiographic files. They had been seen between January 1950 and July 1961 . During this period about 10,000 children with suspected heart disease were studied, so there was thus an incidence of about 0.5 per cent. Estimations of the incidence of the syndrome in unselected children vary from no case in 3400 electrocardiograms (Engle, 1952) to 17 cases in 5500 children (Tamm, 1956). Most authors have found an incidence of about 0.1 per cent in unselected children (Landtman, 1947; Kupatz, 1955; Joseph, Ribierre and Najean, 1958). In children referred for cardiac evaluation the usual reported incidence has been about 0.5 per cent (Métianu and Heim de Balsac, 1954; Hecht et al., 1957; Schiebler et al., 1959a). Our experience confirms this figure.

The criteria for the Wolff-Parkinson-White syndrome in adults as described by Katz and Pick (1956) have been used. These are "the finding (during sinus rhythm) of a short P-R interval and a ventricular complex of abnormal configuration, viz., a QRS deformed and widened in its initial portion, by a slow rising, slurred deflection called a delta wave, and an ST-T more or less opposite in direction to this abnormal deflection." Cases in which delta waves have been seen only during paroxysmal atrial tachycardia, and those in which delta waves have not been present in successive beats have been excluded. In cases in which the longest QRS duration in the standard limb leads was less than $0.10 \mathrm{sec}$., the observed QRS durations have been compared with the longest QRS duration for age as defined by Ziegler (1951). When compared in this way, 12 cases had QRS durations equal to the maximum normal, but only two (1944) had QRS durations slightly shorter than the maximal normal. Ziegler's criteria for the longest normal QRS durations are from right præcordial lead values, which are normally higher than the corresponding values for the

Supported, in part, by a grant from the National Heart Institute (HTS-5310 (C2)), National Institute of Health, United States Public Service, and a Research Fellowship from the National Institute of Health (HTS-5361 (C1)). 
standard limb leads and have been used by us as well as by most other authors (Lepeschkin, 1951; Wolff, 1956) for estimation of QRS duration.

Only patients in whom the conduction abnormality was first detected between birth and 16 years are included. The 48 patients were divided into those without obvious clinical evidence of heart disease (28) and those with clinical, hæmodynamic, or autopsy evidence of heart disease (20).

Analysis of the group without heart disease provides a study of the conduction abnormality with the clinical profile unmodified by any concomitant heart disease. The natural history of the abnormality in childhood, the frequency and importance of paroxysmal atrial tachycardia (PAT), and a critical assessment of the many different forms of treatment of this complication may be derived from this group. Consideration of the group with heart disease and WPW should throw some light on the type of heart disease likely to be associated with the pre-excitation syndrome, as well as on the influence of this conduction abnormality and its consequences on the natural history of underlying heart disease.

The interesting group of cases with central nervous system abnormalities was made up of patients with and without heart disease and is considered separately.

\section{Wolff-Parkinson-White Syndrome Without Evidence of Heart Disease}

There were 28 children ( 20 were boys and 8 were girls) without clinical evidence of heart disease. Of these children 19 had a history of PAT, which in 12 was proven electrocardiographically. In the remaining 9 , there was no history suggestive of PAT.

The findings at a time removed from PAT showed that 15 had heart murmurs which in all but 2 (Cases 27 and 48) were only of Grade I or II intensity (Levine classification 1-6) and deemed to be innocent. One further patient (Case 40) had a systolic murmur as well as an unexplained low intensity apical mid-diastolic rumble but no other features suggesting heart disease.

The heart was normal in size in 27 instances and slightly enlarged in one (Case 8). This boy had no cardiac murmur and had : normal electrocardiogram in the one instance when he showed normal atrioventricular conduction. At no time did he have evidence of congestive heart failure, and digitalization was never necessary. He has not been seen since the age of 17 months, but was known at the age of 11 years to be symptom-free. In one patient no radiograph was taken.

Other authors have noted soft systolic murmurs and top normal or borderline enlargement of the heart in children without any other abnormality apart from the Wolff-Parkinson-White syndrome (Landtman, 1947; Engle, 1952; Knorr, 1956; Schiebler et al., 1959a).

The temporal features of the conduction abnormality are analysed in Table I. Six patients have been seen on one occasion, the remaining 22 have been followed for periods of 11 days to 10 years. Ventricular pre-excitation was a constant feature in 11 patients. Five showed an apparently permanent change from WPW to normal ventricular excitation (Fig. 1), the age at which this change took place varied from 1 to 4 years. Two (Cases 24 and 3) showed a change from a previously

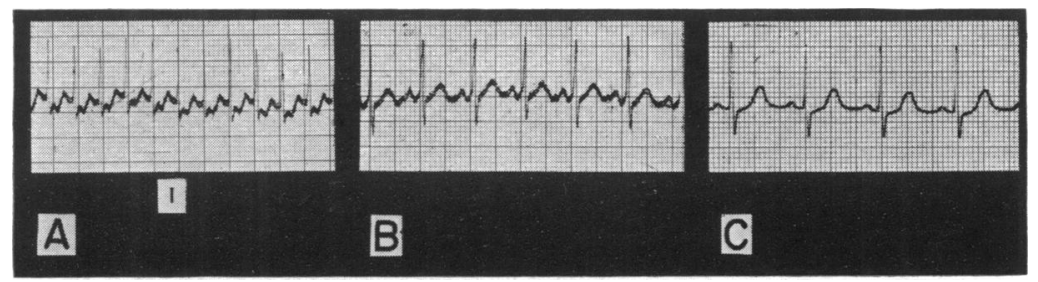

FIG. 1.-Disappearance of ventricular pre-excitation. Case 47. (A) Paroxysmal atrial tachycardia at $2 \frac{1}{2}$ months. (B) WPW with sinus rhythm at $2 \frac{1}{2}$ months. (C). Sinus rhythm with normal atrioventricular conduction at $4 \frac{1}{2}$ years. 
normal cardiogram to ventricular pre-excitation: Case 24 (Fig. 2) had her first cardiogram taken at 14 days because of PAT, but after WPW conduction appeared at 13 months there were no further PAT attacks; Case 3 had a normal cardiogram taken at the age of 5 weeks as part of the general investigation of central nervous system disease, and the first PAT attack occurred at 6 weeks of age, but WPW conduction was not recorded until the age of 10 months. Single instances of two unusual

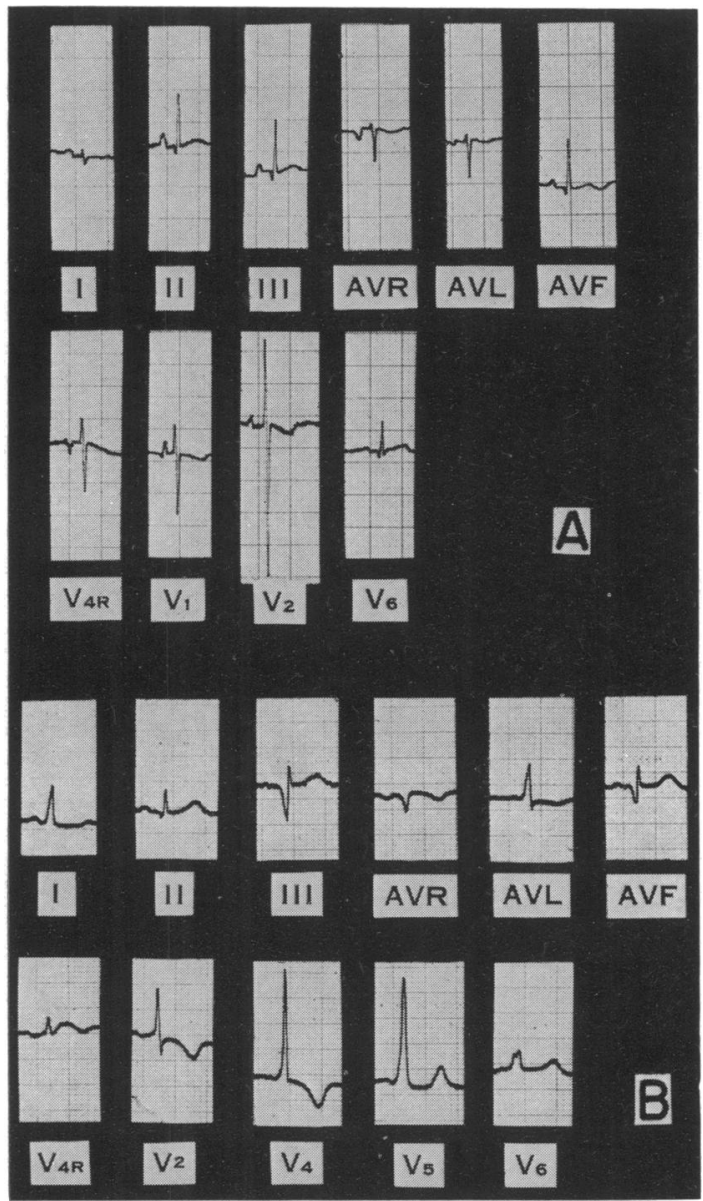

FIG. 2.-Late appearance of ventricular pre-excitation. First evidence of WPW syndrome at 13 months. Case 24. (A) Normal sinus rhythm at 2 weeks. (B) WPW conduction at 4 years of life.

situations were observed: Case 39 showed ventricular pre-excitation with sinus beats but not with nodal beats (Fig. 3), and Case 2, who was only seen on one occasion, showed mostly ventricular preexcitation but with occasional apparently normal ventricular conduction. Finally there were 3 patients who showed intermittent normal ventricular excitation and ventricular pre-excitation in successive records. Fig. 4 demonstrates that the characteristic appearance of ventricular preexcitation may become gradually more obvious with the passage of time, a phenomenon that was seen in several patients with and without heart disease.

The typical curve showing ventricular pre-excitation and normal sinus rhythm has been analysed 


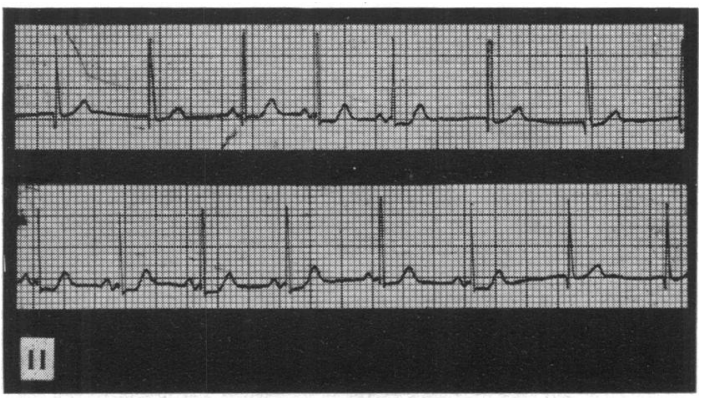

FIg. 3.-Case 39. Periods of sinus rhythm with ventricular pre-excitation alternating with periods of nodal rhythm without delta waves.

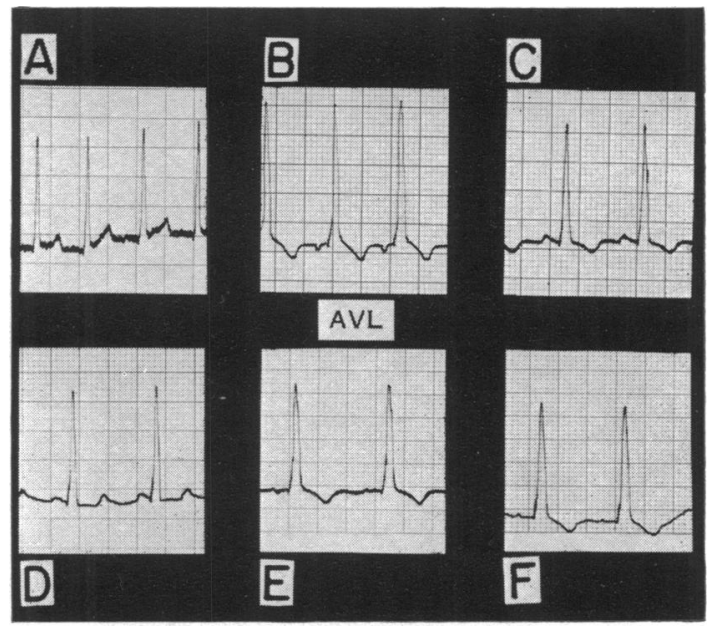

FIG. 4.-Gradual widening of QRS and emergence of characteristic delta wave with passage of time. Case 42. Corrected transposition of the great vessels, pulmonary stenosis, ventricular septal defect. Lead aVL. (A) 10 months, (B) 3 years, (C) 4 years, (D) 6 years, (E) 9 years, and (F) 11 years. QRS widens from $0.07 \mathrm{sec}$. to $0.12 \mathrm{sec}$. Delta wave becomes increasingly obvious.

in each case (Table II). The definitions of Group A and B ventricular pre-excitation are those suggested by Massie and Walsh (1960). In the Group A pattern, upright QRS deflections are registered in all præcordial leads. In the Group B pattern, the right præcordial leads register essentially downward QRS deflections, while the left præcordial leads record upright QRS deflections. In Group A (13 instances) and in Group B (13 instances) ventricular pre-excitation was noted. In 2 patients the group could not be determined since the præcordial leads had not been recorded. It is interesting to note that of the patients without heart disease and no history of PAT, only 1 (Case 7) showed Group A ventricular pre-excitation.

The P-R interval was $0.10 \mathrm{sec}$. or greater (a finding not inconsistent with the diagnosis) in 3 
instances, but was mostly 0.06 to $0.09 \mathrm{sec}$. The longest QRS interval in the standard limb leads varied between 0.08 and $0.16 \mathrm{sec}$. and in no case was less than the normal longest QRS duration for age as defined by Ziegler (1951). Delta waves were usually seen to varying degrees in all leads. In 13 patients there was a normal QRS axis in the frontal plane, in 8 there was left axis deviation, in 6 right axis deviation, and in 1 instance the QRS axis was $-150^{\circ}$. The $\mathrm{T}$ axis in the frontal plane showed, in most instances, a great divergence from the QRS axis, reflecting the characteristic ST-T wave abnormality associated with the syndrome.

TABLE I

WPW Syndrome Without Heart Disease: Temporal Features of Atrioventricular Conduction

\begin{tabular}{|c|c|c|c|c|c|c|}
\hline $\begin{array}{l}\text { Case } \\
\text { No. }\end{array}$ & Sex & $\begin{array}{l}\text { Ventricular } \\
\text { pre-excitation } \\
\text { type }\end{array}$ & $\begin{array}{l}\text { Age EC. } \\
\text { first recorded }\end{array}$ & $\begin{array}{l}\text { Period of } \\
\text { observation } \\
\text { (years) }\end{array}$ & $\begin{array}{l}\text { Number of } \\
\text { EC. } \\
\text { observations }\end{array}$ & $\begin{array}{l}\text { Temporal features of ventricular } \\
\text { pre-excitation }\end{array}$ \\
\hline 7 & $\mathbf{M}$ & A & 6 years & 7 & 3 & Constant \\
\hline 11 & $\mathbf{M}$ & B & 10 years & $4 \frac{1}{2}$ & 3 & Constant \\
\hline 36 & $F$ & B & $3 \frac{1}{2}$ years & & 1 & Only seen once \\
\hline $\begin{array}{l}40 \\
48\end{array}$ & $\begin{array}{l}\mathbf{F} \\
\mathbf{M}\end{array}$ & $\begin{array}{l}\text { B } \\
\mathbf{B}\end{array}$ & $\begin{array}{l}9 \text { years } \\
22 \text { months }\end{array}$ & $\begin{array}{l}6 \\
3\end{array}$ & $\begin{array}{l}5 \\
3\end{array}$ & $\begin{array}{l}\text { Constant } \\
\text { WPW until } 2 \text { years of life, then }\end{array}$ \\
\hline 2 & $\mathrm{~F}$ & B & 10 years & & 1 & $\begin{array}{l}\text { normal } \\
\text { Only seen once, mostly ventricular } \\
\text { pre-excitation, occasional, ap- } \\
\text { parently normal conduction }\end{array}$ \\
\hline 12 & $\mathrm{~F}$ & B & 5 years & 10 & 2 & Constant \\
\hline 20 & M & B & 9 years & 5 & 3 & Constant \\
\hline $\begin{array}{r}21 \\
5\end{array}$ & $\begin{array}{l}\mathbf{M} \\
\mathbf{M}\end{array}$ & $\begin{array}{l}\mathbf{B} \\
\mathbf{A}\end{array}$ & $\begin{array}{l}2 \text { years } \\
1 \text { month }\end{array}$ & & $\begin{array}{l}1 \\
4\end{array}$ & $\begin{array}{l}\text { Only seen once } \\
\text { WPW until } 2 \text { years of life, then }\end{array}$ \\
\hline 6 & M & B & 6 weeks & 2 & 3 & $\begin{array}{l}\text { normal } \\
\text { Constant }\end{array}$ \\
\hline 9 & M & A & 1 month & 2 & 4 & Constant \\
\hline 29 & $\mathbf{M}$ & & 1 month & & 25 & Intermittent \\
\hline 30 & $\mathbf{M}$ & $\begin{array}{l}\text { Only standard } \\
\text { limb leads } \\
\text { recorded }\end{array}$ & 13 months & 1 month & 2 & Constant \\
\hline 35 & M & & 13 years & & 1 & Only seen once \\
\hline 37 & $\mathbf{M}$ & A & 3 months & 10 & 15 & $\begin{array}{l}\text { WPW until age } 18 \text { months, then } \\
\text { normal }\end{array}$ \\
\hline $\begin{array}{l}38 \\
41\end{array}$ & $\begin{array}{l}\mathrm{F} \\
\mathrm{M}\end{array}$ & $\begin{array}{l}\text { B } \\
\text { B }\end{array}$ & $\begin{array}{r}13 \text { years } \\
3 \text { years }\end{array}$ & 1 & $\begin{array}{l}1 \\
2\end{array}$ & $\begin{array}{l}\text { Only seen once } \\
\text { WPW at } 3 \text { years, normal conduction } \\
\text { at } 4 \text { years }\end{array}$ \\
\hline 24 & F & A & 14 days & 4 & 9 & $\begin{array}{l}\text { Normal conduction at } 14 \text { days, } \\
\text { WPW appeared at } 13 \text { months } \\
\text { and has persisted (Fig. 2) }\end{array}$ \\
\hline 18 & $M$ & A & 13 years & 4 months & 2 & Constant \\
\hline 47 & $\mathbf{M}$ & $\begin{array}{l}\text { Only standard } \\
\text { limbs leads } \\
\text { recorded }\end{array}$ & 7 weeks & & 8 & $\begin{array}{l}\text { Changed from WPW to normal } \\
\text { conduction at } 1 \text { year (Fig. 1) }\end{array}$ \\
\hline 8 & $\mathbf{M}$ & A & 13 days & 17 months & 8 & $\begin{array}{l}\text { Intermittent WPW except for one } \\
\text { episode of normal conduction }\end{array}$ \\
\hline 17 & $\mathbf{M}$ & A & 20 days & $4 \frac{1}{2}$ & 6 & $\begin{array}{l}\text { Intermittent until } 34 / 12 \text { years, then } \\
\text { normal }\end{array}$ \\
\hline $\begin{array}{l}27 \\
39\end{array}$ & $\begin{array}{l}\mathrm{F} \\
\mathrm{F}\end{array}$ & $\begin{array}{l}\text { A } \\
\text { A }\end{array}$ & $\begin{array}{r}21 \text { months } \\
4 \text { months }\end{array}$ & $\begin{array}{l}4 \frac{1}{2} \\
\text { month }\end{array}$ & $\begin{array}{l}4 \\
6\end{array}$ & $\begin{array}{l}\text { Constant } \\
\text { Intermittent; ventricular pre-exci- } \\
\text { tation with sinus beats but not } \\
\text { with nodal beats (Fig. } 3 \text { ) }\end{array}$ \\
\hline 3 & $\mathbf{M}$ & A & 5 weeks & $2 \frac{1}{2}$ & 10 & $\begin{array}{l}\text { Normal conduction at } 5 \text { weeks, } \\
\text { onset of WPW at } 10 \text { months, then } \\
\text { constant WPW }\end{array}$ \\
\hline 15 & $\mathbf{M}$ & A & 9 years & & 1 & Only seen once \\
\hline 1 & $\mathbf{M}$ & A & 6 years & 11 days & 3 & Constant \\
\hline
\end{tabular}

First nine cases in Table not subject to bouts of PAT. 


\section{Patients Without Paroxysmal Atrial Tachycardia}

The patients who had no heart disease and showed no evidence of PAT make up the first 9 patients in Tables I and II: boys and girls are equally represented. Predictably, since no attacks of PAT drew the attention of the physician to the heart, the condition was discovered relatively late. In 6 patients a faint murmur drew attention to the condition, in 2 chest pain focused attention to the heart, and in the remaining 1 investigation of obscure central nervous system disease led to taking a cardiogram. Of the 9 patients 8 had type B ventricular pre-excitation.

TABLE II

WPW Syndrome Without Heart Disease: EC. Analysis When in Normal Sinus Rhythm

\begin{tabular}{|c|c|c|c|c|c|c|c|c|c|}
\hline $\begin{array}{l}\text { Case } \\
\text { No. }\end{array}$ & $\begin{array}{l}\text { Age at } \\
\text { EC. } \\
\text { analysis }\end{array}$ & $\begin{array}{c}\text { Ventricular } \\
\text { pre-excitation } \\
\text { type }\end{array}$ & $\begin{array}{c}\text { Heart } \\
\text { rate } \\
\text { beats/min. }\end{array}$ & $\begin{array}{c}\text { Mean } \\
\text { QRS } \\
\text { axis } \\
\text { degrees }\end{array}$ & $\begin{array}{l}\text { Mean } \\
T \text { axis } \\
\text { degrees }\end{array}$ & $\begin{array}{l}\mathbf{P}-\mathbf{R} \\
\text { interval } \\
\text { duration } \\
\text { (sec.) }\end{array}$ & $\begin{array}{l}\text { QRS } \\
\text { dura- } \\
\text { tion } \\
(\mathrm{sec} .)\end{array}$ & $\begin{array}{c}\text { Maxi- } \\
\text { mal } \\
\text { QRS } \\
\text { dura- } \\
\text { tion } \\
\text { for } \\
\text { age } \\
\text { (sec.) }\end{array}$ & $\begin{array}{c}\text { Distribution } \\
\text { of delta } \\
\text { waves }\end{array}$ \\
\hline 7 & 6 years & A & 70 & -5 & +80 & 0.09 & $0 \cdot 11$ & 0.09 & $\begin{array}{l}\text { All leads } \\
\text { except V1 } \\
\text { and V2 }\end{array}$ \\
\hline 11 & 10 years & B & 80 & -30 & +120 & $0 \cdot 12$ & 0.12 & 0.096 & All leads \\
\hline 36 & $3 \frac{1}{2}$ years & B & 110 & +15 & +60 & 0.07 & $0 \cdot 14$ & 0.09 & All leads \\
\hline 40 & 9 years & B & 90 & -35 & +110 & 0.06 & $0 \cdot 12$ & 0.096 & All leads \\
\hline 48 & 22 months & B & 110 & +5 & +50 & 0.08 & 0.09 & 0.08 & All leads \\
\hline 2 & $9 \frac{3}{4}$ years & B & 80 & +15 & +50 & 0.09 & $0 \cdot 12$ & 0.096 & All leads \\
\hline 12 & 5 years & B & 80 & +60 & +45 & 0.07 & $0 \cdot 10$ & 0.09 & $\begin{array}{l}\text { All leads } \\
\text { except III, } \\
\text { V1, and V2 }\end{array}$ \\
\hline 20 & 13 years & B & 90 & +10 & +100 & 0.08 & $0 \cdot 10$ & $0 \cdot 10$ & All leads \\
\hline 21 & 2 years & B & 120 & +60 & +60 & 0.08 & 0.08 & 0.08 & All leads \\
\hline 5 & $1 \frac{1}{2}$ months & A & 148 & +105 & -15 & 0.06 & 0.08 & 0.08 & All leads \\
\hline 6 & 6 weeks & B & 145 & -30 & +100 & 0.09 & $0 \cdot 12$ & 0.08 & All leads \\
\hline 9 & 1 month & $\vec{A}$ & 140 & +110 & +50 & 0.08 & 0.15 & 0.08 & $\begin{array}{l}\text { All leads } \\
\text { except I, } \\
\text { AVF }\end{array}$ \\
\hline 29 & 7 months & B & 120 & -30 & +110 & 0.07 & $0 \cdot 10$ & 0.08 & All leads \\
\hline 30 & 13 months & $\begin{array}{l}\text { Only standard } \\
\text { limb leads }\end{array}$ & 160 & +150 & & 0.06 & 0.09 & 0.08 & $\begin{array}{l}\text { All recorded } \\
\text { leads }\end{array}$ \\
\hline 35 & 13 years & B & 55 & +10 & -105 & 0.09 & $0 \cdot 14$ & $0 \cdot 10$ & All leads \\
\hline 37 & $3 \frac{1}{2}$ months & A & 80 & +90 & +30 & 0.09 & 0.08 & 0.08 & All leads \\
\hline 38 & 13 years & B & 78 & +150 & +105 & $0 \cdot 10$ & $0 \cdot 14$ & $0 \cdot 10$ & All leads \\
\hline 41 & 3 years & B & 102 & +75 & +150 & 0.08 & $0 \cdot 12$ & 0.09 & All leads \\
\hline 24 & 4 years & A & 115 & +15 & +75 & $0 \cdot 11$ & 0.09 & 0.09 & All leads \\
\hline 18 & 13 years & A & 78 & -45 & +45 & 0.07 & $0 \cdot 12$ & $0 \cdot 10$ & All leads \\
\hline 47 & 9 months & $\begin{array}{l}\text { Only standard } \\
\text { limb leads } \\
\text { recorded }\end{array}$ & 145 & +140 & +60 & 0.08 & 0.09 & 0.08 & $\begin{array}{l}\text { All recorded } \\
\text { leads }\end{array}$ \\
\hline 8 & 4 months & A & 160 & +45 & +105 & 0.08 & 0.08 & 0.08 & All leads \\
\hline 17 & 20 days & A & 140 & +180 & +45 & 0.08 & 0.09 & 0.07 & All leads \\
\hline 27 & 21 months & A & 130 & -20 & +45 & 0.08 & 0.08 & 0.08 & All leads \\
\hline 39 & $4 \frac{1}{2}$ months & A & 140 & +90 & +60 & 0.06 & 0.08 & 0.08 & $\begin{array}{l}\text { All leads } \\
\text { except III }\end{array}$ \\
\hline 3 & $1 \frac{1}{2}$ months & A & 150 & -60 & +90 & $\begin{array}{c}\text { variable } \\
0.08\end{array}$ & 0.08 & 0.08 & All leads \\
\hline $\begin{array}{r}15 \\
1\end{array}$ & $\begin{array}{l}8 \frac{1}{2} \text { years } \\
6 \text { years }\end{array}$ & $\begin{array}{l}\mathrm{A} \\
\mathrm{A}\end{array}$ & $\begin{array}{l}78 \\
84\end{array}$ & $\begin{array}{r}+20 \\
-150\end{array}$ & $\begin{array}{r}+60 \\
0\end{array}$ & $\begin{array}{c}\text { to } \\
0.09 \\
0.08 \\
0.07\end{array}$ & $\begin{array}{l}0 \cdot 11 \\
0 \cdot 16\end{array}$ & $\begin{array}{l}0.096 \\
0.09\end{array}$ & $\begin{array}{l}\text { All leads } \\
\text { All leads }\end{array}$ \\
\hline
\end{tabular}

First nine cases in Table not subject to bouts of PAT. 
Follow-up, again quite predictably, was on the whole poor in this group. When last seen they were all doing well from the cardiovascular point of view. A change in the pre-excitation pattern was noted only in one patient (Case 48) who at 2 years of age changed from WPW conduction to normal conduction.

\section{Patients with Paroxysmal Atrial Tachycardia}

Of the 28 patients with no heart disease, 19 had a history of PAT (the last 19 patients in Tables I and II), and in 11 of these the diagnosis was confirmed electrocardiographically. A predominance of boys ( 15 out of 19$)$ is noted in this group, a phenomenon already described for all patients with "idiopathic" PAT (Nadas et al., 1952). Age of discovery is different from the group without PAT for obvious reasons; 9 patients were found to have the WPW syndrome before 4 months of age. An additional 2(24 and 3) in Table I had curves recorded before the age of 4 months but WPW syndrome did not appear until later. The reason for referring these children was PAT or its consequences (cyanosis, dyspnœa, vomiting, etc.), except for Case 3 in whom the first record (which was normal) was taken as part of the investigation of central nervous system disease. Of the 17 patients with chest leads recorded, 12 showed type A ventricular pre-excitation, which is in sharp contrast to the predominance of type B in the group without PAT. The follow-up of this group is much better; it averages 34 months, ranging from no follow-up to 10 years. When last seen, all but one patient (Case 30) who died in a PAT attack, were doing well although 5 still had recurrent attacks of PAT. The temporal features, treatment of the acute attacks, and outcome are detailed in Table III.

The onset of PAT after infancy seems rare. Of the 19 patients 13 had their first attack of PAT before the age of 6 months. Nine of these developed congestive heart failure after periods of tachycardia of 36 hours to six days' duration. One boy of 14 months (Case 30) died in congestive heart failure after four days of tachycardia. It is not certain whether he was having PAT or was in sinus rhythm at the time of death. Autopsy findings will be discussed later.

Death in infants with a normal heart and prolonged paroxysmal tachycardia has been described (Kimball and Burch, 1947; Silverman and Werner, 1950; Vacheron, 1954), but death in older children from PAT alone is a rare event (Wood et al., 1943; Öhnell, 1944; Mortensen et al., 1944; Jordan and Canuteson, 1949; Hecht et al., 1957). Nadas et al. (1952) found three factors that influenced the development of heart failure with paroxysmal tachycardia, namely heart rate, duration of attack, and age of patient. In the present series of paroxysmal tachycardia with WPW conduction disturbance, we have found the same features to hold good. The rate in all instances in which failure developed was over 180 beats a minute, the duration of the attack was at least 36 hours, and the occurrence of failure was confined to those under 18 months of age, providing they had normal hearts.

The signs and symptoms of PAT in the infant age group are well known (Hubbard, 1941; Nadas et al., 1952). They correspond essentially to left- and right-sided failure with reversible cardiomegaly. In the older age group the symptoms are usually of chest pain, dizziness leading sometimes to syncope, sweating, and often palpitation. Nadas et al. (1952) found in their group of 41 patients (5 of whom had WPW syndrome) that if the initial attack occurred before the age of 4 months it was unlikely (4 out of 18 cases) that recurrences would be noted for longer than one year after the onset. Similarly only 3 out of 12 infants in the present series with adequate follow-up are still having attacks.*

It does seem, therefore, that there is a tendency for those who develop PAT in early infancy to be free from recurrence of attacks after about 18 months of age in spite of the presence of WPW.

Treatment of the attacks was along the general lines suggested by previous authors (Hubbard, 1941 ; Nadas et al., 1952). Spontaneous reversion occurred in seven. Digitalis glycoside alone in

\footnotetext{
* Seven of the nine patients without prolonged recurrence have been observed for two years or more after their first
} attack. 
TABLE

Temporal Features: Treatment and Outcome of 19 CASes

\begin{tabular}{|c|c|c|c|c|}
\hline $\begin{array}{l}\text { Case } \\
\text { No. }\end{array}$ & $\begin{array}{l}\text { Age at first attack } \\
\text { of PAT }\end{array}$ & $\begin{array}{l}\text { Age at last known } \\
\text { attack of PAT }\end{array}$ & $\begin{array}{c}\text { Duration of longest } \\
\text { PAT attack }\end{array}$ & Frequency \\
\hline 5 & 6 weeks & 2 years & 6 days & 4 attacks in 2 years \\
\hline 6 & 6 weeks & 3 months & 36 hours + & 3 attacks in first 3 months \\
\hline $\begin{array}{r}9 \\
29\end{array}$ & $\begin{array}{l}\text { Observed in utero } \\
1 \text { month }\end{array}$ & $\begin{array}{l}1 \text { month } \\
8 \text { years }\end{array}$ & $\begin{array}{l}3 \text { to } 4 \text { hours } \\
15 \text { minutes to } 4 \text { hours }\end{array}$ & $\begin{array}{l}3 \text { attacks in } 1 \text { month } \\
\text { Every } 1 \text { to } 3 \text { months }\end{array}$ \\
\hline 30 & Probably 6 months & 14 months (fatal) & 4 days & 6 attacks in 8 months \\
\hline $\begin{array}{l}35 \\
37\end{array}$ & $\begin{array}{l}13 \text { years } \\
3 \frac{1}{2} \text { months }\end{array}$ & $\begin{array}{l}\text { Only one attack } \\
4 \text { months }\end{array}$ & $\begin{array}{l}15 \text { minutes } \\
36 \text { hours }\end{array}$ & $\begin{array}{l}\text { Only one attack } \\
3 \text { attacks in } 1 \text { month, none after } \\
\text { age } 4 \text { months }\end{array}$ \\
\hline $\begin{array}{l}38 \\
41 \\
24 \\
18 \\
47\end{array}$ & $\begin{array}{l}13 \text { years } \\
3 \text { months } \\
12 \text { days } \\
10 \text { years } \\
7 \text { weeks }\end{array}$ & $\begin{array}{l}\text { Only one attack } \\
3 \text { years } \\
18 \text { months } \\
13 \text { years } \\
9 \text { weeks }\end{array}$ & $\begin{array}{l}4 \text { hours } \\
24 \text { hours } \\
2 \text { days } \\
45 \text { minutes } \\
3 \text { days }\end{array}$ & $\begin{array}{l}\text { Only one attack } \\
4 \text { attacks in } 3 \text { years } \\
4 \text { attacks in } 1 \frac{1}{2} \text { years } \\
4 \text { attacks in } 3 \text { years } \\
2 \text { attacks in first } 9 \text { weeks of life }\end{array}$ \\
\hline 8 & 11 days & 17 months & 2 days & 3 attacks at 11 days, 14 days, \\
\hline $\begin{array}{l}17 \\
27 \\
39\end{array}$ & $\begin{array}{l}\text { At birth } \\
2 \frac{1}{4} \text { years } \\
4 \text { months }\end{array}$ & $\begin{array}{l}2 \text { months } \\
\text { Only one attack } \\
\text { Only one attack }\end{array}$ & $\begin{array}{l}15 \text { to } 30 \text { minutes } \\
2 \text { hours } \\
3 \text { days }+\end{array}$ & $\begin{array}{l}\text { Frequent attacks up to } 2 \text { months } \\
\text { Only one attack } \\
\text { Only one attack observed }\end{array}$ \\
\hline 3 & 6 weeks & 3 years & 3 days & $5-6$ in 2 years \\
\hline $\begin{array}{r}15 \\
1\end{array}$ & $\begin{array}{l}7 \text { years } \\
3 \text { years }\end{array}$ & $\begin{array}{l}\text { Only one attack } \\
6 \text { years }\end{array}$ & $\begin{array}{l}5 \text { minutes } \\
15 \text { days? }\end{array}$ & $\begin{array}{l}\text { Only one attack } \\
5-6 \text { per year }\end{array}$ \\
\hline
\end{tabular}

the usual doses (Nadas et al., 1952) effectively terminated the attack in 5 and, in combination with reflex vagal stimulation, in an additional one. Four patients did not respond to digitalis: 3 of these were successfully treated with a combination of digitalis and quinidine. The fourth (Case 30) died with a very unusual sequence of events which will be described later. Pronestyl was effectively used in the final case, since the cardiogram resembled ventricular tachycardia.

It is interesting to note the number of patients who did not respond to digitalis alone. This is in some contrast to the almost invariable effectiveness of digitalis in patients with "idiopathic" PAT (Nadas et al., 1952).

Prophylactic therapy was attempted in 9 of the 19 patients without heart disease, but was considered unnecessary in the others. Table III demonstrates that the isolated use of digitalis is often partially successful in the control of PAT attacks. Experiences with 6 further patients with heart disease including one (Case 10, to be described later) whose attacks were finally reduced in number by the use of $4 \mathrm{~g}$. of quinidine a day indicate that quinidine used alone or in combination with digitalis probably constitutes the most effective prophylactic therapy. In the present series, recurrent PAT attacks have presented a real medical problem only in 2 patients (Cases 10 and 30), and both these died probably as a consequence of arrhythmias. As far as can be determined neither digitalis nor quinidine had any specific effect upon the conduction abnormality. An apparently variable effect of digitalis on atrioventricular conduction was seen in Case 14 (Fig. 7) and in Case 26, but no constant relation between mode of ventricular excitation and drug therapy could be found. 
III

OF WPW Syndrome With PAT but no Heart Disease

\begin{tabular}{|c|c|c|c|}
\hline $\begin{array}{c}\text { Treatments used for longest } \\
\text { PAT attacks }\end{array}$ & $\begin{array}{l}\text { Most effective method of } \\
\text { treatment of PAT attacks }\end{array}$ & Prophylaxis of PAT attacks & Outcome \\
\hline $\begin{array}{l}\text { Digoxin; quinidine; vagal } \\
\text { stimulation; prostigmine }\end{array}$ & $\begin{array}{l}\text { Orbital compression while } \\
\text { on digoxin and quinidine }\end{array}$ & $\begin{array}{l}\text { Attacks controlled by orbital } \\
\text { pressure, when on digoxin }\end{array}$ & Well \\
\hline $\begin{array}{l}\text { Vagal stimulation; procaina- } \\
\text { mide }\end{array}$ & $\begin{array}{l}\text { Pronestyl; reverted after } \\
\text { 5th intramuscular dose }\end{array}$ & $\begin{array}{l}\text { and quinidine } \\
\text { None }\end{array}$ & Well \\
\hline $\begin{array}{l}\text { Vagal stimulation; digoxin } \\
\text { Vagal stimulation; digoxin, } \\
\text { quinidine }\end{array}$ & $\begin{array}{l}\text { Digoxin } \\
\text { Digoxin and quinidine }\end{array}$ & $\begin{array}{l}\text { Digoxin, effective } \\
\text { Digoxin and quinidine } \\
\text { partially effective }\end{array}$ & $\begin{array}{l}\text { Well } \\
\text { Still has PAT attacks }\end{array}$ \\
\hline Vagal stimulation; digoxin & $\begin{array}{l}\text { Reverted spontaneously, } \\
\text { PAT followed digitali- } \\
\text { zation for cardiac failure }\end{array}$ & None & Died \\
\hline $\begin{array}{l}\text { Spontaneous cessation } \\
\text { Vagal stimulation; cedilanid }\end{array}$ & Cedilanid & $\begin{array}{l}\text { None } \\
\text { Quinidine, effective }\end{array}$ & $\begin{array}{l}\text { Well } \\
\text { Well }\end{array}$ \\
\hline $\begin{array}{l}\text { Spontaneous cessation } \\
\text { Vagal stimulation; digoxin } \\
\text { Vagal stimulation; digoxin } \\
\text { Spontaneous cessation } \\
\text { Vagal stimulation; cedilanid, } \\
\text { quinidine }\end{array}$ & $\begin{array}{l}\text { Digitoxin } \\
\text { Digoxin } \\
\text { Digoxin and quinidine }\end{array}$ & $\begin{array}{l}\text { None } \\
\text { Digitoxin, partially effective } \\
\text { Digoxin, ineffective } \\
\text { None } \\
\text { Digitoxin, effective }\end{array}$ & $\begin{array}{l}\text { Well } \\
\text { Still has PAT attacks } \\
\text { Well } \\
\text { Still has PAT attacks } \\
\text { Well }\end{array}$ \\
\hline Vagal stimulation; oxygen & Spontaneous with oxygen & None & Well \\
\hline $\begin{array}{l}\text { Spontaneous cessation } \\
\text { Spontaneous cessation } \\
\text { Vagal stimulation; phenobar- } \\
\text { bital, digoxin }\end{array}$ & Probably digoxin & $\begin{array}{l}\text { None } \\
\text { None } \\
\text { None }\end{array}$ & $\begin{array}{l}\text { Well } \\
\text { Well } \\
\text { No follow up }\end{array}$ \\
\hline $\begin{array}{l}\text { Digoxin; quinidine; ipecacu- } \\
\text { anha }\end{array}$ & $\begin{array}{l}\text { Ipecacuanha while on } \\
\text { digoxin }\end{array}$ & Digoxin ineffective & Still has PAT \\
\hline $\begin{array}{l}\text { Spontaneous cessation } \\
\text { Purodigin; quinidine; } \\
\text { methacholine, "digalen" }\end{array}$ & Intramuscular "digalen" & $\begin{array}{l}\text { None } \\
\text { Digitalis folia partially } \\
\quad \text { successful }\end{array}$ & $\begin{array}{l}\text { Well } \\
\text { Still has PAT }\end{array}$ \\
\hline
\end{tabular}

\section{Wolff-Parkinson-White Syndrome Associated with Heart Disease}

Reports of the association of the WPW syndrome with congenital heart disease appeared in the early 1940's (Kiss, 1941; Nádrai, 1941; Pohlmann, 1941; Öhnell, 1944). Two reports in 1946 (Bodlander, 1946; Moore and Dimond, 1946) described patients with coarctation of the aorta and the WPW syndrome. The association of the conduction abnormality with Ebstein's malformation was described by Sodi-Pallares and Marsico (1955), and recent publications have confirmed the association (Schiebler et al., 1958 and 1959c) particularly with type B ventricular pre-excitation. Schiebler et al. (1959a) found that $24(29 \%)$ out of 83 reported cases of WPW syndrome with associated congenital heart disease had been diagnosed as having Ebstein's anomaly. Other associations found were dextrocardia without congenital heart disease (Plavšić, 1949; Bartholomew and Burchell, 1952) and, to a less striking degree, tricuspid atresia.

The association of familial cardiomegaly with the WPW syndrome is now well known, having been reported by Campbell and Turner-Warwick (1956), Soulié et al. (1957), and Schiebler et al. (1959b). Other associations noted have been with rheumatic heart disease (Bain and Hamilton, 1926; Schiebler et al., 1959a), primary myocardial disease (Hecht et al., 1957), and thyrotoxicosis (Strong, 1949).

\section{General Observations}

The temporal features of the conduction abnormality and the incidence and treatment of PAT in this group are presented in Table IV. Individual cardiograms are analysed in Table V. There were 
TABLE IV

WPW Syndrome with Heart Disease: Temporal Features of Atrioventricular Conduction Incidence and TREATMENT OF PAT

\begin{tabular}{|c|c|c|c|c|c|c|c|c|c|}
\hline $\begin{array}{l}\text { Case } \\
\text { No. }\end{array}$ & Sex & Diagnosis & $\begin{array}{l}\text { Ventri- } \\
\text { cular } \\
\text { pre- } \\
\text { excita- } \\
\text { tion } \\
\text { type }\end{array}$ & $\begin{array}{l}\text { Age at } \\
\text { first } \\
\text { EC. } \\
\text { (years) }\end{array}$ & $\begin{array}{l}\text { Period } \\
\text { of } \\
\text { obser- } \\
\text { vation } \\
\text { (years) }\end{array}$ & $\begin{array}{l}\text { No. } \\
\text { of } \\
\text { EC. }\end{array}$ & $\begin{array}{l}\text { Temporal } \\
\text { features } \\
\text { of WPW }\end{array}$ & $\begin{array}{l}\text { Paroxysmal } \\
\text { atrial } \\
\text { tachycardia }\end{array}$ & Outcome \\
\hline 16 & $\mathbf{M}$ & $\begin{array}{c}\text { Ebstein's } \\
\text { anomaly } \\
\text { Ebstein's }\end{array}$ & B & $4 \frac{1}{2}$ & $\frac{1}{2}$ & 2 & Constant & None & $\begin{array}{l}\text { Sudden death } \\
\text { after } \\
\text { swimming at } \\
14 \text { years } \\
\text { Alive }\end{array}$ \\
\hline 28 & $\mathrm{~F}$ & $\begin{array}{c}\text { anomaly } \\
\text { Ebstein's } \\
\text { anomaly }\end{array}$ & B & 2 months & $4 \frac{1}{2}$ & 13 & $\begin{array}{l}\text { Constant } \\
\text { QRS } \\
\text { widened } \\
\text { from } 0.09 \text { to } \\
\mathbf{0 . 1 2}\end{array}$ & None & $\begin{array}{l}\text { Died at } 49 / 12 \\
\text { years }\end{array}$ \\
\hline 46 & $\mathbf{M}$ & $\begin{array}{l}\text { Ebstein's } \\
\text { anomaly }\end{array}$ & B & 11 days & 7 days & 3 & Intermittent & None & $\begin{array}{l}\text { Died at } 16 \\
\text { days in } \\
\text { heart failure }\end{array}$ \\
\hline 32 & F & $\begin{array}{l}\text { Corrected } \\
\text { transposition } \\
\text { of G.V.* }\end{array}$ & B & 4 weeks & $4 \frac{1}{2}$ & 8 & $\begin{array}{l}\text { Constant; } \\
\text { QRS } \\
\text { widened } \\
\text { from } 0.085 \\
\text { to } 0 \cdot 13\end{array}$ & $\begin{array}{l}\text { PAT } \\
\text { effectively } \\
\text { controlled by } \\
\text { digoxin }\end{array}$ & Alive \\
\hline 42 & $F$ & $\begin{array}{l}\text { Corrected } \\
\text { transposition } \\
\text { of G.V. }\end{array}$ & B & $3 \frac{1}{2}$ & $7 \frac{1}{2}$ & 10 & Constant & None & Alive \\
\hline 43 & $\mathbf{M}$ & $\begin{array}{l}\text { Corrected } \\
\text { transposition } \\
\text { of G.V. }\end{array}$ & B & 3 & $9 \mathrm{mo}$. & 2 & Constant & $\begin{array}{l}\text { During } \\
\text { catheteri- } \\
\text { zation only }\end{array}$ & Alive \\
\hline 33 & F & $\begin{array}{l}\text { Familial } \\
\text { myocardial } \\
\text { disease }\end{array}$ & B & $11 \frac{1}{2}$ & 6 & 16 & Constant & $\begin{array}{l}\text { PAT; } \\
\text { digoxin and } \\
\text { quinidine } \\
\text { almost } \\
\text { completely } \\
\text { effective } \\
\text { in prophy- } \\
\text { laxis; } \\
\text { reserpine } \\
\text { ineffective }\end{array}$ & Alive \\
\hline 34 & $\mathbf{M}$ & $\begin{array}{l}\text { Familial } \\
\text { myocardial } \\
\text { disease }\end{array}$ & B & $14 \frac{1}{2}$ & $\frac{1}{2}$ & 10 & Constant & $\begin{array}{l}\text { PAT; } \\
\text { quinidine } \\
\text { alone partially } \\
\text { effective } \\
\text { in attacks, } \\
\text { and for } \\
\text { prophylaxis }\end{array}$ & Alive \\
\hline 26 & F & $\begin{array}{l}\text { Primary } \\
\text { myocardial } \\
\text { disease }\end{array}$ & B & 2 months & 5 & 5 & $\begin{array}{l}\text { Changed } \\
\text { from WPW } \\
\text { to normal } \\
\text { conduction } \\
\text { at } 2 \frac{1}{2} \text { months }\end{array}$ & None & Alive \\
\hline 19 & $\mathbf{M}$ & $\begin{array}{l}\text { Primary } \\
\text { myocardial } \\
\text { disease }\end{array}$ & B & $6 \frac{1}{2}$ & $3 \frac{1}{2}$ & 4 & Constant & $\begin{array}{l}\text { PAT; } \\
\text { no } \\
\text { prophylaxis }\end{array}$ & $\begin{array}{l}\text { Died at } 10 \\
\text { years in heart } \\
\text { failure }\end{array}$ \\
\hline 10 & F & $\begin{array}{l}\text { Primary } \\
\text { myocardial } \\
\text { disease }\end{array}$ & $?$ & 7 months & 20 & 50 & Constant & $\begin{array}{l}\text { PAT; } \\
\text { quinidine } \\
\text { alone up to } \\
4 \text { g./day; } \\
\text { most } \\
\text { effective } \\
\text { in prophy- } \\
\text { laxis }\end{array}$ & $\begin{array}{l}\text { Died at } 20 \\
\text { years } \\
\text { suddenly }\end{array}$ \\
\hline
\end{tabular}


TABLE IV-continued

\begin{tabular}{|c|c|c|c|c|c|c|c|c|c|}
\hline $\begin{array}{l}\text { Case } \\
\text { No. }\end{array}$ & Sex & Diagnosis & $\begin{array}{l}\text { Ventri- } \\
\text { cular } \\
\text { pre- } \\
\text { excita- } \\
\text { tion } \\
\text { type }\end{array}$ & $\begin{array}{l}\text { Age at } \\
\text { first } \\
\text { EC. } \\
\text { (years) }\end{array}$ & $\begin{array}{l}\text { Period } \\
\text { of } \\
\text { obser- } \\
\text { vation } \\
\text { (years) }\end{array}$ & $\begin{array}{l}\text { No. } \\
\text { of } \\
\text { EC. }\end{array}$ & $\begin{array}{l}\text { Temporal } \\
\text { features } \\
\text { of WPW }\end{array}$ & $\begin{array}{l}\text { Paroxysmal } \\
\text { atrial } \\
\text { tachycardia }\end{array}$ & Outcome \\
\hline 13 & $\mathbf{M}$ & $\begin{array}{l}\text { Ventricular } \\
\text { septal defect }\end{array}$ & B & 9 months & $4 \frac{1}{4}$ & 5 & Constant & $\begin{array}{l}\text { PAT; } \\
\text { no }\end{array}$ & Alive \\
\hline 23 & F & $\begin{array}{l}\text { Coarctation } \\
\text { of aorta, } \\
\text { patent } \\
\text { ductus } \\
\text { arteriosus }\end{array}$ & B & $5 \frac{1}{4}$ & $1 \frac{3}{4}$ & 5 & Constant & $\begin{array}{l}\text { prophylaxis } \\
\text { PAT during } \\
\text { operation } \\
\text { only, no } \\
\text { prophylaxis }\end{array}$ & Alive \\
\hline 31 & $\mathbf{M}$ & $?$ & B & 7 & 5 & 12 & Constant & $\begin{array}{l}\text { PAT; attacks } \\
\text { controlled } \\
\text { by orbital } \\
\text { compression } \\
\text { when on } \\
\text { digitalis and } \\
\text { quinidine }\end{array}$ & Alive \\
\hline 45 & $\mathbf{M}$ & $\begin{array}{l}\text { Ventricular } \\
\text { septal defect } \\
\text { with aortic } \\
\text { regurgitation }\end{array}$ & B & 1 & 9 & 5 & Constant & None & Alive \\
\hline 44 & $F$ & $\begin{array}{l}\text { Pulmonic } \\
\text { stenosis } \\
\text { ventricular } \\
\text { septal defect }\end{array}$ & A & 2 months & $3 \frac{1}{2}$ & 5 & $\begin{array}{l}\text { Changed } \\
\text { from WPW } \\
\text { to normal } \\
\text { conduction } \\
\text { at } 19 / 12 \\
\text { years }\end{array}$ & None & Alive \\
\hline $\begin{array}{l}25 \\
22\end{array}$ & $\begin{array}{l}\mathrm{M} \\
\mathrm{F}\end{array}$ & 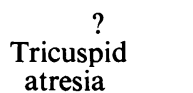 & $\begin{array}{l}\text { B } \\
\text { B }\end{array}$ & $\begin{array}{l}6 \frac{1}{2} \\
2 \frac{1}{2}\end{array}$ & $\begin{array}{l}6 \frac{1}{2} \\
5\end{array}$ & $\begin{array}{l}2 \\
8\end{array}$ & $\begin{array}{l}\text { Constant } \\
\text { Constant }\end{array}$ & $\begin{array}{l}\text { None } \\
\text { None }\end{array}$ & $\begin{array}{l}\text { Alive } \\
\text { Alive }\end{array}$ \\
\hline 14 & M & $\begin{array}{l}\text { Acute } \\
\text { rheumatic } \\
\text { myocarditis } \\
\text { and } \\
\text { pericarditis }\end{array}$ & ? & 15 & $3 \mathrm{mo}$. & 50 & Intermittent & $\begin{array}{l}\text { PAT; } \\
\text { variable } \\
\text { effect of } \\
\text { digoxin } \dagger\end{array}$ & Alive \\
\hline
\end{tabular}

* Great vessels.

$\dagger$ Variable effect of digitalis is shown in Fig. 7.

4 cases of Ebstein's malformation of the tricuspid valve, 3 of corrected transposition of the great arteries, and 5 cases of myocardial disease. The remaining 8 patients showed miscellaneous forms of heart disease.

In contrast to those with normal hearts, the sexes were equally represented in the total group with heart disease: of the 9 patients with PAT there were 5 boys and 4 girls. The curves showed constant ventricular pre-excitation in 16 instances, intermittent WPW in 2, and a change from WPW to normal ventricular excitation in 2 . It seems, therefore, that there is a greater tendency for ventricular pre-excitation to be constant and permanent in those with heart disease than in those with normal hearts. Type B ventricular pre-excitation was seen in 17 of 18 patients in whom præcordial leads were recorded. This is in sharp contrast to the findings in the group with no heart disease. Nine patients in the heart disease group showed a P-R interval of $0.10 \mathrm{sec}$. or greater, and in 2 others the QRS duration was slightly shorter than the maximal normal for age. The longer P-R intervals found in those with heart disease may be related to atrial hypertrophy, but the pathogenesis is not clear. The P-R segment was never greater than 50 per cent of normal as defined by Ziegler (1951), and in several instances no P-R segment was present.

PAT was present in $9(45 \%)$ out of 20 , compared to $19(68 \%)$ out of 28 with normal heats. As 
TABLE V

WPW Syndrome with Heart Disease : EC. Analysis when in Normal Sinus Rhythm

\begin{tabular}{|c|c|c|c|c|c|c|c|c|c|}
\hline $\begin{array}{l}\text { Case } \\
\text { No. }\end{array}$ & $\begin{array}{c}\text { Age at } \\
\text { EC. } \\
\text { analysis } \\
\text { (years) }\end{array}$ & $\begin{array}{l}\text { Ventricular } \\
\text { pre-excitation } \\
\text { type }\end{array}$ & $\begin{array}{c}\text { Heart } \\
\text { rate } \\
\text { (beats/ } \\
\text { min.) }\end{array}$ & $\begin{array}{c}\text { Mean } \\
\text { QRS } \\
\text { axis } \\
\text { (degrees) }\end{array}$ & $\begin{array}{c}\text { Mean } \\
\text { T axis } \\
\text { (degrees) }\end{array}$ & $\begin{array}{c}\text { P-R } \\
\text { interval } \\
\text { (sec.) }\end{array}$ & $\begin{array}{c}\text { QRS } \\
\text { duration } \\
\text { (sec.) }\end{array}$ & $\begin{array}{c}\text { Maximal } \\
\text { normal } \\
\text { QRS } \\
\text { duration } \\
\text { for age } \\
\text { (sec.) }\end{array}$ & $\begin{array}{l}\text { Distribution } \\
\text { of delta } \\
\text { waves }\end{array}$ \\
\hline $\begin{array}{c}4 \\
16 \\
28 \\
46^{*}\end{array}$ & $\begin{array}{l}9 \\
4 \frac{1}{2} \\
2 \text { months } \\
14 \text { days }\end{array}$ & $\begin{array}{l}\text { B } \\
\text { B } \\
\text { B } \\
\text { B }\end{array}$ & $\begin{array}{r}80 \\
125 \\
132 \\
120\end{array}$ & $\begin{array}{r}-25 \\
-60 \\
-30 \\
+170\end{array}$ & $\begin{array}{c}+75 \\
+60 \\
+30 \\
\text { indeterminate }\end{array}$ & $\begin{array}{l}0 \cdot 10 \\
0 \cdot 10 \\
0 \cdot 10 \\
0 \cdot 13\end{array}$ & $\begin{array}{l}0 \cdot 11 \\
0 \cdot 12 \\
0 \cdot 09 \\
0 \cdot 12\end{array}$ & $\begin{array}{l}0.096 \\
0.09 \\
0.08 \\
0.07\end{array}$ & $\begin{array}{l}\text { All leads } \\
\text { All leads } \\
\text { All leads } \\
\text { All leads } \\
\text { except III, } \\
\text { AVL,AVF, } \\
\text { V5 and 6 }\end{array}$ \\
\hline $\begin{array}{l}32 \\
42 \\
43\end{array}$ & $\begin{array}{l}1 \text { month } \\
11 \\
3 \frac{1}{2}\end{array}$ & $\begin{array}{l}\text { B } \\
\mathbf{B} \\
\mathbf{B}\end{array}$ & $\begin{array}{l}175 \\
106 \\
120\end{array}$ & $\begin{array}{l}-40 \\
-60 \\
+70\end{array}$ & $\begin{array}{r}+90 \\
+105 \\
0\end{array}$ & $\begin{array}{l}0.09 \\
0 \cdot 13 \\
0 \cdot 10\end{array}$ & $\begin{array}{l}0 \cdot 85 \\
0 \cdot 12 \\
0 \cdot 10\end{array}$ & $\begin{array}{l}0.07 \\
0 \cdot 10 \\
0.09\end{array}$ & $\begin{array}{l}\text { All leads } \\
\text { All leads } \\
\text { All leads } \\
\text { except } \\
\text { AVR, AVL, } \\
\text { V1, and V2 }\end{array}$ \\
\hline $\begin{array}{l}33 \\
34 \\
26 \\
19 \\
10 \\
13 \\
23 \\
31 \\
45 \\
44\end{array}$ & $\begin{array}{l}14 \\
14 \frac{1}{2} \\
2 \text { months } \\
6 \frac{1}{2} \\
13 \\
9 \text { months } \\
5 \frac{1}{4} \\
10 \\
2 \\
2 \text { months }\end{array}$ & $\begin{array}{l}\text { B } \\
\text { B } \\
\text { B } \\
\text { B } \\
\text { ? } \\
\text { B } \\
\text { B } \\
\text { B } \\
\text { B } \\
\text { A }\end{array}$ & $\begin{array}{r}90 \\
68 \\
120 \\
106 \\
75 \\
150 \\
104 \\
70 \\
130 \\
155\end{array}$ & $\begin{array}{l}+40 \\
+30 \\
+40 \\
+70 \\
-20 \\
-20 \\
-45 \\
-20 \\
-30 \\
+110\end{array}$ & $\begin{array}{c}-120 \\
+150 \\
-100 \\
-90 \\
+160 \\
+60 \\
+110 \\
+60 \\
+75 \\
\text { indeterminate }\end{array}$ & $\begin{array}{l}0.08 \\
0.08 \\
0.07 \\
0.09 \\
0.08 \\
0.09 \\
0.08 \\
0 \cdot 12 \\
0.11 \\
0.08\end{array}$ & $\begin{array}{l}0 \cdot 16 \\
0 \cdot 10 \\
0.09 \\
0.08 \\
0 \cdot 16 \\
0 \cdot 10 \\
0 \cdot 12 \\
0 \cdot 10 \\
0 \cdot 18 \\
0.07\end{array}$ & $\begin{array}{l}0 \cdot 10 \\
0 \cdot 10 \\
0.08 \\
0.09 \\
0 \cdot 10 \\
0.08 \\
0.09 \\
0 \cdot 10 \\
0.08 \\
0.08\end{array}$ & $\begin{array}{l}\text { All leads } \\
\text { All leads } \\
\text { All leads } \\
\text { All leads } \\
\text { All leads } \\
\text { All leads } \\
\text { All leads } \\
\text { All leads } \\
\text { All leads } \\
\text { Present in I, } \\
\text { AVR, AVL, } \\
\text { V2, V4, V5, } \\
\text { and V6 }\end{array}$ \\
\hline $\begin{array}{l}25 \\
22 \\
14\end{array}$ & $\begin{array}{r}6 \frac{1}{2} \\
7 \frac{1}{4} \\
15\end{array}$ & $\begin{array}{l}\text { B } \\
\text { B } \\
?\end{array}$ & $\begin{array}{l}100 \\
110 \\
125\end{array}$ & $\begin{array}{l}+45 \\
-45 \\
-30\end{array}$ & $\begin{array}{l}-105 \\
+100 \\
+180\end{array}$ & $\begin{array}{l}0.07 \\
0 \cdot 10 \\
0.08\end{array}$ & $\begin{array}{l}0.12 \\
0.09 \\
0 \cdot 14\end{array}$ & $\begin{array}{l}0.09 \\
0.09 \\
0 \cdot 10\end{array}$ & $\begin{array}{l}\text { All leads } \\
\text { All leads } \\
\text { All leads }\end{array}$ \\
\hline
\end{tabular}

* This 2-week-old infant showed two apparently different types of ventricular pre-excitation.

mentioned previously, the isolated use of quinidine or its use in combination with digitalis was found to be the most effective therapy in control of the acute attack and in prophylaxis. The effect of the conduction abnormality on the natural history of the heart disease is difficult to assess but one patient certainly (Case 10) and 2 patients probably (Cases 4 and 46) died following cardiac arrhythmias. A fourth patient (Case 34) with multiple severe attacks of PAT and other supraventricular arrhythmias associated with angina refractory to treatment seems likely to have a worse prognosis because of his conduction abnormality.

\section{Group I: Ebstein's Malformation of the Tricuspid Valve}

There were 4 patients with Ebstein's anomaly and WPW syndrome. Three of these were proven at autopsy, and in the fourth the clinical features (Mayer, Nadas, and Ongley 1957) as well as the catheter findings (Vacca, Bussmann, and Mudd, 1958), including intracardiac records, were pathognomonic. The summary of these is presented in Table VI. It is interesting to note that all 4 had type B ventricular pre-excitation and that none had any evidence of ever having had PAT.

\section{Group II: Corrected Transposition of the Great Arteries}

Three patients were diagnosed as having corrected transposition of the great arteries. Two of these had the classical clinical and catheterization features of this abnormality as described by 
TABLE VI

Findings in Four Cases of Ebstein's Malformation of the Tricuspid Valve ASSOCIATED WITH WPW SYNDROME

\begin{tabular}{c|c|c|c|c|c|c}
\hline $\begin{array}{c}\text { Case } \\
\text { No. }\end{array}$ & $\begin{array}{c}\text { Clinical } \\
\text { impression }\end{array}$ & PAT & Radiograph & $\begin{array}{c}\text { Ventricular } \\
\text { pre-excitation } \\
\text { type }\end{array}$ & $\begin{array}{c}\text { Cardiac } \\
\text { catheterization }\end{array}$ & Autopsy \\
\hline 4 & $\begin{array}{l}\text { Ebstein's } \\
\text { anomaly }\end{array}$ & No & $\begin{array}{l}\text { Cardiomegaly; } \\
\text { diminished } \\
\text { pulmonary } \\
\text { vasculature }\end{array}$ & B & None & $\begin{array}{c}\text { Ebstein's } \\
\text { malformation } \\
\text { with tricuspid } \\
\text { and mitral } \\
\text { insufficiency } \\
\text { Alive }\end{array}$ \\
$\begin{array}{c}\text { Ebstein's } \\
\text { anomaly or } \\
\text { primary } \\
\text { myocardial } \\
\text { disease } \\
\text { Ventricular septal } \\
\text { defect with } \\
\text { pulmonary } \\
\text { arterial } \\
\text { hypertension }\end{array}$ & No & $\begin{array}{l}\text { Cardiomegaly; } \\
\text { normal or } \\
\text { diminished } \\
\text { pulmonary } \\
\text { vasculature } \\
\text { Cardiomegaly; } \\
\text { increased } \\
\text { pulmonary } \\
\text { vasculature }\end{array}$ & B & B & $\begin{array}{l}\text { Pathognomonic } \\
\text { findings of } \\
\text { Ebstein's } \\
\text { malformation } \\
\text { Ventricular septal } \\
\text { defect; pul- } \\
\text { monary arterial } \\
\text { hypertension, } \\
\text { mitral } \\
\text { regurgitation }\end{array}$ & $\begin{array}{l}\text { Ventricular septal } \\
\text { defects of } \\
\text { muscular and } \\
\text { membranous } \\
\text { septum; Ebstein's } \\
\text { malformation of } \\
\text { tricuspid valve; } \\
\text { dilated mitral } \\
\text { valve } \\
\text { Ebstein's } \\
\text { anomaly; } \\
\text { hypoplastic aortic } \\
\text { arch; coarctation } \\
\text { of aorta; patent } \\
\text { ductus arteriosus }\end{array}$ \\
\hline 46 & $\begin{array}{l}\text { Ebstein's } \\
\text { anomaly }\end{array}$ & No & $\begin{array}{l}\text { Marked } \\
\text { cardiomegaly }\end{array}$ & B & None & \\
\hline
\end{tabular}

Schiebler et al. (1961). In the third patient the great arteries were in the classical corrected transposition relation to each other; however, the pulmonary artery saturation was somewhat higher than systemic artery saturation and, in addition, coarctation of the aorta with a "reversed ductus" was also present. The summary of these patients is presented in Table VII.

The WPW syndrome was present in 1 of the 33 cases of corrected transposition described by Schiebler et al. (1961), but among 83 cases of WPW syndrome associated with congenital heart

TABLE VII

Findings in Three Patients with Corrected Transposition of the Great Arteries and WPW Syndrome

\begin{tabular}{|c|c|c|c|c|c|}
\hline $\begin{array}{l}\text { Case } \\
\text { No. }\end{array}$ & $\begin{array}{l}\text { Clinical } \\
\text { diagnosis }\end{array}$ & PAT & Radiograph & $\begin{array}{l}\text { Ventricular } \\
\text { pre-excitation } \\
\text { type }\end{array}$ & $\begin{array}{c}\text { Cardiac } \\
\text { catheterization }\end{array}$ \\
\hline 32 & Mitral regurgitation & Yes & $\begin{array}{l}\text { Slight cardiomegaly; } \\
\text { normal pulmonary } \\
\text { vasculature }\end{array}$ & B & $\begin{array}{l}\text { Corrected transposition of } \\
\text { great arteries; mitral regur- } \\
\text { gitation }\end{array}$ \\
\hline 42 & $\begin{array}{l}\text { Tetralogy of Fallot } \\
\text { (Blalock } \\
\text { anastomosis) }\end{array}$ & No & $\begin{array}{l}\text { Slight cardiomegaly; } \\
\text { abnormally placed } \\
\text { great vessels }\end{array}$ & B & $\begin{array}{l}\text { Ventricular septal defect; } \\
\text { pulmonicstenosis;corrected } \\
\text { transposition of great ves- } \\
\text { sels }\end{array}$ \\
\hline 43 & $\begin{array}{l}\text { Endocardial cushion } \\
\text { defect with } \\
\text { pulmonary arterial } \\
\text { hypertension }\end{array}$ & No & $\begin{array}{l}\text { Moderate cardiomegaly, } \\
\text { slightly increased } \\
\text { pulmonary vasculature }\end{array}$ & B & $\begin{array}{l}\text { Ventricular septal defect; } \\
\text { pulmonary arterial hyper- } \\
\text { tension; coarctation of } \\
\text { aorta; patent ductus arterio- } \\
\text { sus; corrected transposition } \\
\text { of great vessels }\end{array}$ \\
\hline
\end{tabular}


disease of their own and collected from the published reports, Schiebler et al. (1959a) found no case of corrected transposition. It is possible that one or more of the three cases of transposition of the great vessels with WPW syndrome described (Fiorio, 1953; Hejtmancik and Herrmann, 1957; Schiebler et al., 1958; Schiebler et al., 1959c) may have, in fact, corrected transposition.

\section{Group III: Primary Myocardial Disease}

There were 5 patients in whom a reasonably secure diagnosis of "primary myocardial disease" could be made. Two of these were siblings (Cases 33 and 34) but the other three appeared to be sporadic cases. Fig. 5 demonstrates the family tree of Cases 33 and 34, their mother had cardio-

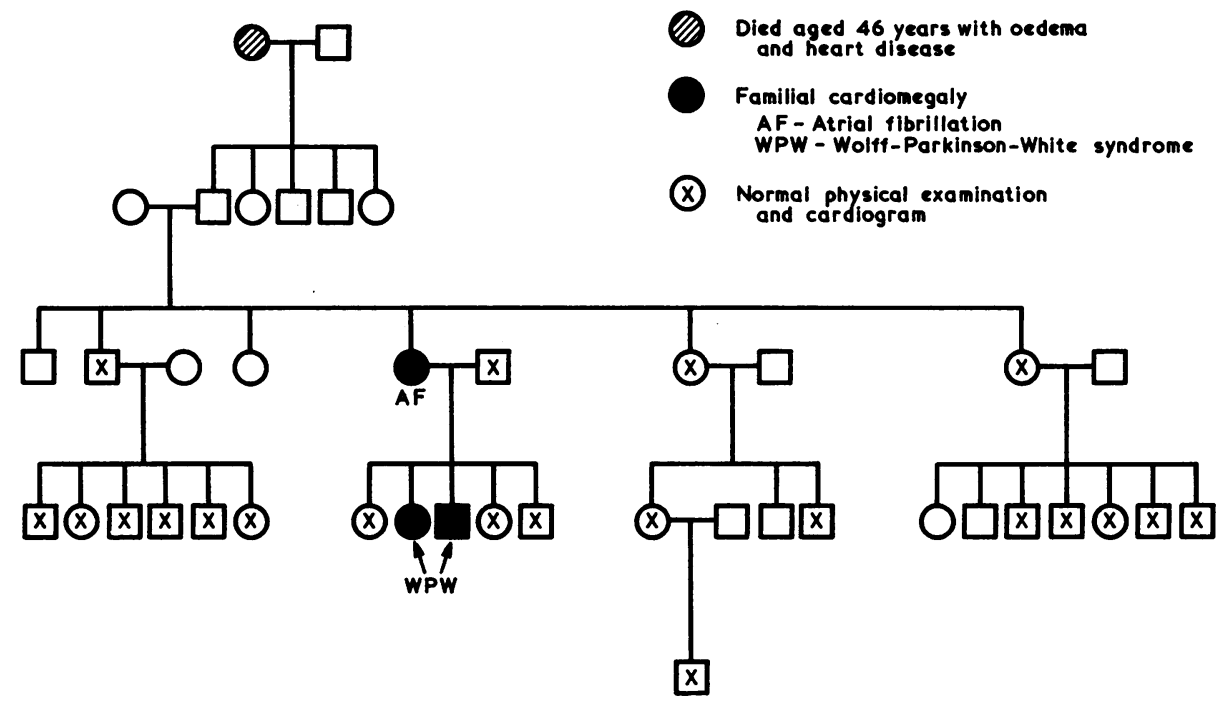

FIG. 5.-Family tree. Familial myocardial disease with WPW syndrome. Case 33 (black circle WPW) and Case 34 (black square WPW).

megaly and atrial fibrillation, and the mother's grandmother died at 46 years of age with œdema and heart disease. Many of the other family members have been examined physically and electrocardiographically, but no other instances of heart disease have been found.

Brief case histories of the two siblings and the three sporadic cases are given. PAT occurred in 4 of the 5 and was particularly difficult to prevent in three.

Case 33. This 17-year-old girl developed exertional dyspnœa, easy fatiguability, and presumed, though unproven, attacks of paroxysmal atrial tachycardia at 10 years of age. A Grade III apical pansystolic murmur suggestive of mitral regurgitation was detected. A chest film, taken at the age of 5 years when she attended the hospital because of an orthopædic problem, showed a normal-sized heart, and at that time there was no suspicion of heart disease; at 13 years there was slight cardiomegaly, and at 16 years there was considerable cardiomegaly with predominant enlargement of the left ventricle and left atrium. Her record showed ventricular pre-excitation type B. Because of signs of early congestive heart failure and doubt concerning diagnosis, she was catheterized. The study revealed raised end diastolic pressure in left and right ventricles of $18 \mathrm{~mm} . \mathrm{Hg}$ and $11 \mathrm{~mm} . \mathrm{Hg}$ respectively with correspondingly raised atrial pressures. There was no evidence from the left atrial pressure tracing of mitral regurgitation, but this was strongly suspected clinically. A diagnosis of primary myocardial disease was made, and her congestive heart failure was treated with digitoxin and her PAT with digoxin, quinidine, and reserpine. Her complaints of tachycardia have become less numerous, but she is becoming more breathless on effort. It is interesting to note that at the time of her examination at 11 years, a Grade III apical systolic murmur was the only finding on physical examination suggestive of congenital heart disease and that early in life she had a normal-sized heart. 
Case 34. This 15-year-old boy was first brought to our attention six years after we had been taking care of his sister. The mother, suspecting the boy of malingering,! brought him in with "presumable" chest pain, which occurred while shovelling snow. A cardiogram revealed atrial fibrillation. Exertional dyspnœa has been more rapidly progressive and well-documented PAT attacks have been more numerous than in the sister. Because the time of onset of his arrhythmia was not known, he was given a three-week course of anticoagulant therapy before attempting conversion to sinus rhythm with quinidine. The use of quinidine alone proved effective in his conversion where use of digitalis and quinidine together resulted in an increase in the ventricular rate and subsequently the production of PAT with block (Fig. 6).

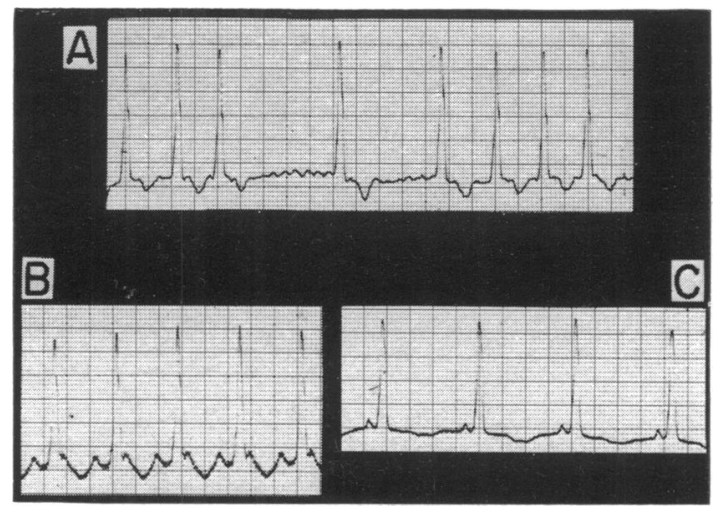

FIG. 6.-Variable atrial arrhythmias in patient with familial myocardial disease and WPW type $B$. Case 34. (A) Atrial fibrillation. (B) Paroxysmal atrial tachycardia with atrioventricular block 2:1 response. (C) Regular sinus rhythm with WPW.

The heart showed clinical left ventricular enlargement and hypertrophy and the first heart sound was soft but no murmur was present. Chest radiographs demonstrated cardiac enlargement which has been progressive even over his seven-month period of observation. In sinus rhythm his curve showed ventricular pre-excitation type B. His SGOT was consistently raised to levels as high as $\mathbf{3 8 0}$ units (normal for laboratory 30 to 50 units), but it was not further raised during an exercise test on a variable resistance bicycle ergometer. It was decided not to subject him to cardiac catheterization, because, in view of the hæmodynamic findings in his sister, the diagnosis of primary familial myocardial disease seemed certain.*

Case 26. This 5-year-old girl had an illness at 7 weeks of age characterized by respiratory distress and vomiting. A diagnosis of acute myocarditis was strengthened by the findings of a Grade II blowing apical systolic murmur, significant persistent cardiac enlargement on the radiographs, and ventricular pre-excitation type B on her cardiogram. She made a spontaneous recovery with appearance of normal ventricular excitation, disappearance of the cardiac murmur, and now after five years of follow-up, radiological examination of her heart reveals that it has almost returned to normal size. There has been no recurrent ventricular pre-excitation and no history suggestive of paroxysmal atrial tachycardia at any time.

Case 19. This boy, who died at the age of 10 years, was first seen at the age of 6 years when he entered the hospital with pneumonia. At this time the heart was found to be enlarged with the radiological appearance of pulmonary venous engorgement and auscultatory findings suggestive of mitral regurgitation. His first cardiogram showed PAT and, after reversion to sinus rhythm with digitalis, ventricular pre-excitation type B. After recovery from pneumonia right heart catheterization revealed a pulmonary artery wedge pressure elevated to $14-21 \mathrm{~mm}$. $\mathrm{Hg}$. A diagnosis of primary myocardial disease, probably endocardial fibro-elastosis with mitral valve involvement, was made. Congestive heart failure appeared at the age of 8 years, and he died in chronic heart failure at 10 years. There was no recurrent PAT after his attack of pneumonia, and his record continued to show ventricular pre-excitation. No autopsy was performed.

Case 10. This girl, who died at the age of 20 years, was first seen at 7 months because of paroxysmal atrial tachycardia. Throughout her life she continued to have innumerable attacks of PAT often resulting in con-

* Since completion of this paper, this boy died suddenly. Autopsy revealed cardiomyopathy. 
gestive heart failure. Many drugs were used in efforts to convert her to normal sinus rhythm, the most effective for this purpose and also for the prevention of attacks was quinidine sulphate, given prophylactically in doses as high as $4 \mathrm{~g}$. per day.

A heart murmur was first noted at the age of 7 months, and by the age of 20 months it was interpreted by competent cardiologists as the murmur of aortic regurgitation. Her first chest radiograph at the age of 15 months showed cardiac enlargement which was progressive through the years. Ventricular preexcitation type B has been present on over 50 records. At the age of 18 years she became hirsute, and an abdominal tumour which proved to be an arrhenoblastoma was removed. At 20 years of age, while working as a student nurse, she was found dead in her room, her finger pointing at the quinidine bottle. At that time she was on prophylactic quinidine $4 \mathrm{~g}$. a day with no evidence of toxicity. Autopsy demonstrated a scarred hypertrophied myocardium with areas of acellular fibrous tissue. The aortic valve was thickened with acellular hyaline material at its roots; the cusps were irregular and the valve incompetent. Histological examination suggested an old thrombotic endocarditis. Both mitral and aortic valves showed evidence of old valvulitis, but there was no evidence of rheumatic heart disease. Also present was a nodular colloid goitre. Clearly, even after autopsy examination, the ætiology of heart disease is uncertain in this patient but appeared to be primary myocardial disease with aortic and mitral valve involvement.*

\section{Group IV: Miscellaneous Heart Disease}

There were 8 patients with miscellaneous heart disease. There were one each of clear-cut, surgically- or catheter-proven patients with tricuspid atresia, tetralogy of Fallot, and coarctation with patent ductus arteriosus. It is worth noting that the sibling of the last patient died with Ebstein's anomaly and WPW syndrome (Case 46). In addition, there is one patient each with the presumptive diagnosis of ventricular septal defect and ventricular septal defect with aortic regurgitation. One patient in the series had WPW syndrome associated with acute rheumatic fever. It is not known whether the conduction abnormality was present before the onset of rheumatic fever or not. The case was mainly of interest because of the intermittent character of the WPW disturbance and the apparent variable effect of digitalis (cedilanid) on the conduction abnormality as shown in Fig. 7.

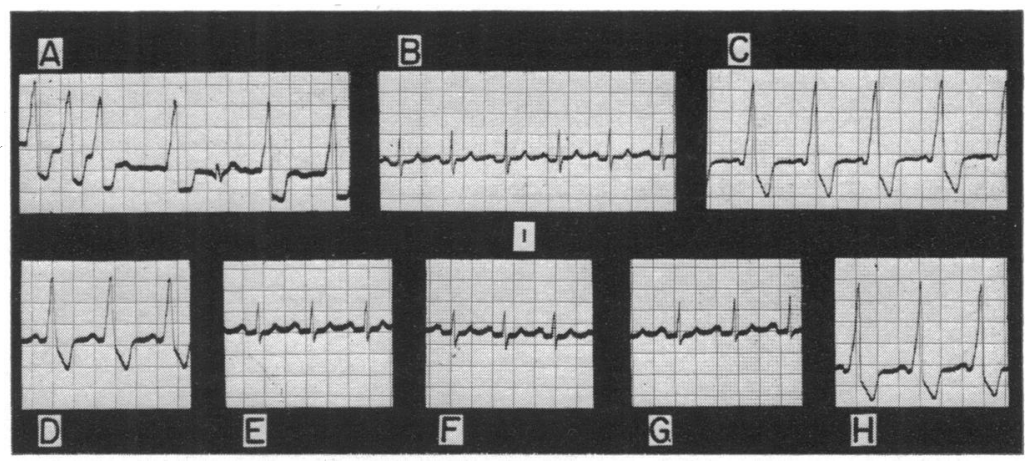

FIG. 7.-Apparent variable effect of digitalis in a patient with acute rheumatic fever. Case 14 (all tracings standard limb lead I). (A) $11 / 2 / 50$. Atrial fibrillation with "WPW like" QRS complexes. (B) 12/8/50. Normal atrioventricular conduction before administration of digitalis. (C) $12 / 9 / 50$. Three hours after cedilanid: typical WPW conduction. (D) $12 / 10 / 50$. Three hours after cedilanid: typical WPW conduction. (E) $12 / 10 / 50$. Twelve hours after cedilanid: normal atrioventricular conduction. (F) 12/11/50. One and a half hours after digitalis : normal atrioventricular conduction. (G) $12 / 11 / 50$. Five hours after digitalis: normal atrioventricular conduction. (H) 12/11/50. Ten hours after digitalis: typical WPW syndrome.

The patient died with acute carditis, and at autopsy there was fibrous and fibrinous pericarditis and gross ventricular hypertrophy and dilatation. The edges of the mitral valve cusps were thickened

* We are indebted to Dr. A. Friedlich for information concerning the last three years of this patient's life. 
and rolled, and there was great thickening of the papillary muscles of the left ventricle. The gross and microscopic appearances were felt to be those of acute rheumatic carditis.

Finally, in two patients no diagnosis worth quoting could be made, but the evidence of cardiac enlargement and a greater than Grade III murmur in each case led to the assumption that they had heart disease. One of these two had a normal left heart catheterization.

\section{Central Nervous System Abnormality Associated with Wolff-Parkinson-White Syndromi*}

The association of WPW with central nervous system disorders has been known for many years (Puddu and Mu Safia, 1939; Wood et al., 1943; Lind, 1944; Mortensen et al., 1944; Rosenbaum et al., 1945; Moore and Dimond, 1946; Jonnart et al., 1949; Evans, 1949; Fiorio, 1953; Søndergaard, 1953; Scott and Tuna, 1953; Mustakallio and Saikkonen, 1953; Seganti and Varcasia, 1954; Tamm, 1956; Hajtmancik and Herrmann, 1957; Yim and Yu, 1958). Out of the 48 patients presented, we found 9 with central nervous system abnormalities. It is interesting to note that there was a tenth patient (Case 33) whose initial presentation simulated epileptic attacks, but following the findings of a normal neurological examination, negative electroencephalogram, and the documentation of PAT attacks by cardiogram, it is finally felt that "epileptic" attacks were of cardiovascular rather than of central nervous system origin.

Brief case histories are presented to illustrate the wide variation in the central nervous system disease.

Case 39. This girl was delivered by cæsarian section because of a large head producing cephalopelvic disproportion. She remained well without evidence of heart disease or central nervous system abnormality until the age of 4 months, when she developed bronchopneumonia with fever, coma, convulsions, and PAT. She made a complete recovery and is thought to have no permanent central nervous system abnormality.

Case 3. Following cæsarian section for material toxæmia of pregnancy, this boy developed severe jaundice lasting three weeks. No exchange transfusion was given. Subsequently the child exhibited a spastic diplegia with leg "scissoring," increased deep tendon reflexes, and delayed motor development. His electroencephalogram was normal. There was no evidence of heart disease but attacks of PAT have been frequent.

Case 30. Following a normal birth and neonatal period, this boy developed convulsions at the age of 7 months and 9 months, and a third episode appeared to be responsible for his death at 14 months. There was no evidence of heart disease, but recurrent attacks of PAT, not related to his convulsions, occurred between 6 months and his death. Between attacks of PAT and convulsions, no abnormality was evident apart from the findings of ventricular pre-excitation on the cardiogram. The electroencephalogram was normal. At the time of his final admission, the history suggested that he had had PAT for about three days. Immediate digitalization was planned, but he reverted to sinus rhythm before the first dose was given. He was, however, then digitalized because of congestive heart failure but reverted to PAT while on digitalis. A few hours later his body was noted to stiffen and he developed cardiac respiratory arrest; internal cardiac massage with mouth-to-mouth breathing resulted in a spontaneous heart beat but he died four hours later following ventricular arrhythmias. Autopsy demonstrated a slightly œdematous brain with a small subarachnoid hæmorrhage on the left lateral surface, and two hæmorrhages $1 \mathrm{~cm}$. in diameter, one in the cerebellar posterior pole of each cerebellar hemisphere.

Case 23. This girl, who was born of a normal pregnancy and delivery, had a remarkable family history. Of 3 siblings, the first died aged 3 to 4 days with "cyanosis and an enlarged heart," the second sibling is alive and well following division of a patent ductus arteriosus, and the third sibling died at 14 days of age, autopsy showing a coarctation, patent ductus arteriosus, and Ebstein's malformation of the tricuspid valve (Case 46). The patient under discussion was operated on for a patent ductus arteriosus and a coarctation of the aorta. PAT developed only at the time of surgery. She is mentally retarded with microcephaly and an intelligence quotient of 50 . She still has a residual murmur and cardiomegaly but has not been catheterized.

Case 12. After a normal pregnancy but difficult forceps delivery, this girl developed convulsive seizures at the age of 15 months. Later the seizures became more suggestive of autonomic epilepsy and she was noted to be "slow at school." The electroencephalogram was reported as mildly abnormal,

* We are indebted to Dr. C. Lombroso for helping us to evaluate the neurological status of these patients. 
with bursts of irregular slow action in the parietal and occipital leads, exaggerated by overventilation. The changes were thought compatible with epilepsy. The patient has no evidence of heart disease or PAT. The first cardiogram was taken at the age of 5 years as part of the investigation of seizures.

Case 20. After spontaneous rupture of the membranes three weeks before delivery, this boy had a normal birth and neonatal period. Subsequently it became apparent that he was mentally retarded and psychological evaluation indicated "dull normal or borderline intelligence." The child also has enuresis. There has been no evidence of heart disease or PAT, but at 8 years of age, while investigating a cardiac murmur later thought to be innocent, the cardiogram showed WPW syndrome.

Case 21. A diagnosis of tuberous sclerosis has been made in both the patient and his father. After a normal birth this boy developed myoclonic seizures, incoordination, and generalized muscular hypotonia. He showed severe mental retardation and later developed shagreen skin. His electroencephalogram was grossly abnormal with continuous spike wave complexes of high voltage. There is no evidence of heart disease or PAT. The cardiogram was obtained because of the known association between rhabdomyoma of the heart and tuberous sclerosis.

Case 25. Following a normal birth and neonatal history, this boy developed convulsive seizures at the age of 6 years. These seizures became progressively more severe and were sometimes confined to the left side of the body; in addition, he showed mild mental retardation. A pneumo-encephalogram showed moderate ventricular dilatation consistent with brain atrophy and brain biopsy showed multiple small infarcts in the cerebral cortex. His electro-encephalogram was abnormal because of diffuse irregular slow activity, rhythmic and non-rhythmic replacing much of the normal resting rhythm. He is thought, on the basis of a Grade III systolic murmur at the lower left sternal border and a slightly enlarged heart as shown on. a radiograph, with normal pulmonary vasculature, possibly to have an Ebstein's malformation of the tricuspid valve. There is no history suggestive of PAT.

Case 45. Multiple congenital anomalies, consisting of bony abnormalities of the elbows and forearms, macrocrania, and areas of pigmented skin over the head and trunk, were noted at birth in this male child. Convulsions, which were thought to be due possibly to hypocalcæmia, occurred in the neonatal period. At the present time the child has had no further convulsions, is of normal intelligence, and has a normal neurological examination; however an arrested hydrocephalus is thought to be present. He is thought to have congenital heart disease, possibly a ventricular septal defect with aortic regurgitation or a coronary arteriovenous fistula. There has been no history of PAT.

No satisfactory explanation has been found to account for the association of central nervous system disease with WPW syndrome. Previous explanations have included anoxic brain damage during bouts of tachycardia, emboli originating from the left side of the heart, the association of congenital anomalies of brain and heart, and the occurrence of Stokes-Adams attacks precipitating unconsciousness and seizures. The possibility that seizures may be related to paroxysmal tachycardia is certainly not ruled out. The occurrence of seizures during repetitive ventricular paroxysmal arrhythmia has been described by one of us (Świderski, Obodowska-Zysk, and Wierzejksa, 1960; Lenartowska and Świderski, 1961), and the association of seizures resulting from the cerebral anoxia of Stokes-Adams attacks is well known.

Of the 9 patients described, Case 39 would normally be designated "febrile convulsions," Case 3 "congenital spastic diplegia" resulting probably from kernicterus, Case 12 "convulsive seizures and autonomic epilepsy resulting from birth trauma," Case 21 "mental retardation and seizures associated with tuberous sclerosis," and Case 45 "neonatal convulsions probably on the basis of hypo- O calcæmia": this latter case was found later to have hydrocephalus. Cases 23 and 20 both showed mental retardation as the sole central nervous system abnormality, and in Case 23 there was microcephaly and a remarkable history of heart disease in siblings. Cases 30 and 25 represent the most interesting situations. Case 30 had prolonged tachycardia of four days' duration and terminally developed seizures: at autopsy two small fresh cerebellar hæmorrhages were found and one small fresh subarachnoid hæmorrhage, suggesting a causal relation of the paroxysmal tachycardia to the cerebral pathology. Case 25 with heart disease of uncertain diagnosis did not have any history of PAT, but nevertheless the findings of cortical atrophy by pneumo-encephalography and multiple cortical infarcts by brain biopsy are strongly suggestive of multiple small emboli originating from the left side of the heart. 
The findings, therefore, suggest multiple ætiologies for the central nervous system abnormalities associated with the WPW syndrome, and no clear single picture of ætiology emerges from analysis of these cases or others reported.

\section{Summary AND CONCLUSIONS}

Forty-eight infants and children with the Wolff-Parkinson-White syndrome were seen in a tenyear period at the Children's Hospital Medical Center. This represents an approximate incidence of 0.5 per cent among children with "suspected" heart disease.

Among 28 without clinical evidence of heart disease, 15 had innocent murmurs and only 1 showed questionable cardiac enlargement. Twenty-two of these patients had been seen on more than one occasion and the pre-excitation syndrome was found to be constant in only half of them. Nine of them, all but one with Type B pre-excitation, had never been reported to have an attack of PAT. Among the 19 patients with PAT, type A pre-excitation was more common, and there was male predominance. Treatment of the paroxysmal rapid heart action was not entirely successful with digitalis and the use of quinidine was necessary in some for treatment as well as for prophylaxisRecurrence of PAT beyond 18 months of age was rare. One child in this group died with convulsions, not clearly associated with PAT.

Among the 20 patients with heart disease, those with Ebstein's malformation (4), corrected transposition of the great arteries (3), and primary myocardial disease (5) predominated; 7 of the 8 others have single instances of congenital heart disease, and the eighth had acute rheumatic carditis. The conduction abnormality was constant in 16, and corresponded in all but one to Type B. PAT was evident in less than half of these patients, but there were 3 fatalities, 1 certainly and 2 probably associated with tachycardia.

Associated central nervous system abnormalities were present in 9 patients, some with, and others without, heart disease. Four of these had attacks of PAT, two of them having close temporal association with central nervous system symptoms.

\section{REFERENCES}

Bain, C. W. C., and Hamilton, C. K. (1926). Lancet, 1, 807.

Bartholomew, L. G., and Burchell, H. B. (1952). Proc. Mayo Clin., 27, 98.

Bodlander, J. W. (1946). Amer. Heart J., 31, 785.

Bulgarelli, R. (1955). Minerva pediat., 7, 535.

Campbell, M., and Turner-Warwick, M. (1956). Brit. Heart J., 18, 393.

Engle, M. A. (1952). A.M.A. Amer. J. Dis. Child., 84, 692.

Evans, W. (1949). Brit. Heart J., 11, 68.

Fiorio, G. (1953). Minerva pediat., 5, 245.

Hecht, H. H. et al. (1957). Panel discussion. Ann. N. Y. Acad. Sci., 65, 826.

Hejtmancik, M. R., and Herrmann, G. R. (1957). Amer. Heart J., 54, 708.

Hubbard, J. P. (1941). Amer. J. Dis. Child., 61, 687.

Jonnart, L., Meyer, J., and Van Landschoot, O. (1949). Acta cardiol. (Brux.), 4, 381.

Jordan, R. A., and Canuteson, R. I. (1949). J.-Lancet, 69, 38.

Joseph, R., Ribierre, M., and Najean, Y. (1958). Ann. Pediat., 34, 92.

Katz, L. N., and Pick, A. (1956). Clinical Electrocardiography, Part I, p. 679. Lea and Febiger, Philadelphia.

Kimball, J. L., and Burch, G. (1947). Ann. intern. Med., 27, 239.

Kiss, P. von (1941). Arch. Kinderheilk, 122, 29.

Knorr, D. (1956). Arch. Kinderheilk, 154, 28.

Kupatz, H. (1955). Neue öst. Z. Kinderheilk, 1, 59.

Landtman, B. (1947). Acta paediat. (Uppsala), 34, Suppl. 1.

Lenartowska, I., and Świderski, J. (1961). Pediat. pol., 36, 277.

Lepeschkin, E. (1951). Modern Electrocardiography, Vol. 1, p. 278. Williams and Wilkins, Baltimore.

Lind, J. (1944). Acta paediat (Uppsala), 32, 153.

Massie, E., and Walsh, T. J. (1960). Clinical Vectorcardiography and Electrocardiography, p. 483. Year Book Publishers, Chicago.

Mayer, F. E., Nadas, A. S., and Ongley, P. A. (1957). Circulation, 16, 1057.

Métianu, C., and Heim de Balsac (1954). In Traité des Cardiopathies Congénitales, p. 1025, ed. E, Donzelot, and F. d'Allines. Masson, Paris.

Moore, R. M., and Dimond, G. (1946). J. Indiana med. Ass., 39, 352.

Mortensen, V., Nielsen, A. L., and Eskildsen, P. (1944). Acta med. scand., 118, 506. 
Mustakallio, K. K., and Saikkonen, J. I. (1953). Amer. Heart J., 46, 607.

Nadas, A. S., Daeschner, C. W., Roth, A., and Blumenthal, S. L. (1952). Pediatrics, 9, 167.

Nádrai, A. (1941). Ergebn. inn. Med. Kinderheilk, 60, 688.

Öhnell, R. F. (1944). Acta. med. scand., 118, Suppl. 152.

Pohlmann, F. (1941). Z. klin. Med., 140, 1.

Plavšić, C. (1949). Arch. Mal. Caur., 42, 1221.

Puddu, V., and Mu Safia, A. (1939). Arch. Mal. Caur., 32, 958.

Rosenbaum, F. F., Hecht, H. H., Wilson, F. N., and Johnston, F. D. (1945). Amer. Heart J., $29,281$.

Schiebler, G. L., Adams, P., and Anderson, R. C. (1959a). Pediatrics, 24, 585.

$-,-,-(1959$ b). Amer. Heart J., 58, 113.

,,--- - Amplatz, K., and Lester, R. G. (1958). A.M.A. J. Dis. Child., 96, 540.

$-,-,-\ldots,-, \ldots,(1959 \mathrm{c})$. Circulation, 19, 165

Scott, T., and Tuna, N. (1953). Trans. Amer. clin. climat. Ass., 65, 215.

Seganti, A., and Varcasia, E. (1954). Pediat. int. (Roma), 4, 67.

Silverman, J. J., and Werner, M. (1950). J. Pediat., 37, 765.

Sodi-Pallares, D., and Marsico, F. (1955). Amer. Heart J., 49, 202.

Søndergaard, G. (1953). Acta. med. scand., 145, 386.

Soulié, P., di Mattéo, J., Abaza, A., Nouaille, J., and Thibert, M. (1957). Arch. Mal. Cour., 50, 22.

Sroczynska, M., and Korczowski, R. (1959). Pediat. pol., 34, 1336.

Strong, J. A. (1949). Lancet, 1, 959.

Świderski, J., Obodowska-Zysk, W., and Wierzejska, H. (1960). Pediat. pol., 35, 1349.

Tamm, R. H. (1956). Hel. paediat. Acta., 11, 78.

Vacca, J. B., Bussmann, D. W., and Mudd, J. G. (1958). Amer. J. Cardiol., 2, 210.

Vacheron, P. (1954). Arch. Mal. Cour, 47, 345.

Wolff, L. (1956). Electrocardiography, Fundamentals and Clinical Applications, 2nd ed, p. 116. Saunders, Philadelphia and London.

Wood, F. C., Wolferth, C. C., and Geckeler, G. D. (1943). Amer. Heart J., 25, 454.

Yim, B. J. B., and Yu, P. N. (1958). Circulation, 17, 543.

Ziegler, R. F. (1951). Electrocardiographic Studies in Normal Infants and Children. Thomas, Springfield, Illinois. 